\title{
A Zooarchaeological Study on the Origins of Animal Domestication in Ancient China
}

\author{
YUAN Jing 袁靖1
}

(Institute of Archaeological Science, Fudan University, Shanghai 200433, China; Institute of Archaeology, Chinese Academy of Social Sciences, Beijing 100710, China)

\begin{abstract}
A series of criteria such as morphological metrics, pathology, age structure, sex ratios, relative proportions, archaeological phenomena, diet analysis, and DNA studies are established for identifying the origins of domestic animals in ancient China in a scientific way. Using these criteria, it is established that the earliest domestic dog has been found in southern Hebei Province (ca. 10,000 BP), and the earliest domestic pig in southern Henan Province (ca. 9000 BP). Domestic sheep have been found in the Gansu-Qinghai region dating from 5600-5000 BP, and domestic cattle in eastern Gansu Province (ca. 5000 BP). Domestic horses from the period 4000-3600 BP have been discovered in eastern Gansu, and domestic chickens have been identified from sites in eastern Henan Province dating to ca. 3300 BP. Although the locations and time of the origins of animal domestication vary, they are mostly located in northern China.
\end{abstract}

Keywords: zooarchaeology, identification criteria, dog, pig, sheep, cattle, horse, chicken

摘 要: 通过确立科学判断中国古代家养动物起源的系列依据（如形体测量、病理现象、 年龄结构、性别比例、数量比例、考古现象、食性分析和 DNA 研究), 可以断定: 距今 约 10000 年, 在河北省南部出现狗; 距今约 9000 年, 在河南省南部出现猪; 距今约 5600 5000 年, 在甘青地区出现绵羊; 距今约 5000 年, 在甘肃省东部出现黄牛; 距今约 4000 3600 年, 在甘肃省东部出现马; 距今约 3300 年, 在河南省东部出现鸡。这些家养动物分 别起源或出现于不同的时间和不同的地点, 但基本上都位于中国的北方地区。

关键词: 动物考古学, 判断依据, 狗, 猪, 绵羊, 黄牛, 马, 鸡

Received: March 30, 2017. Revised: March 25, 2020.

* The original version of this article was published in Chinese as "Zooarchaeological Study on the Domestic Animals in Ancient China" (Zhongguo gudai jiayang dongwu de dongwu kaoguxue yanjiu 中国古代家养动物的动物考古学研究) in Quaternary Sciences (Disiji yanjiu 第四纪研究) 30 (2): 298-306 in 2010 and has been revised and translated into English for this re-publication. This article has been copyedited by John Moffett.

1 Research interests: Archaeological science, human-environmental interactions in ancient times, and zooarchaeology on human-animal relations in ancient societies. Email: yuanj@fudan.edu.cn 
$\mathrm{Z}$ ooarchaeology aims to explore the relationship between ancient humanity and animals through faunal remains from archaeological sites. The origins of animal domestication have always been an issue of great concern in zooarchaeology worldwide, because the rise of domestic animals fundamentally changed the human-animal relationship. The domestication of animals enabled humans to plan a steady meat supply, as well as easy access to animal milk, fur, eggs, and other byproducts, as well as their use as tools for ploughing, carrying, riding, and driving. In addition, animal domestication promoted the emergence of private property and social complexity, increased the risk of animal-caused diseases, and reduced meat diversity in the human diet.

In China, there is an old proverb: "The five crops produce bumper harvests, and the six livestock are all thriving” (五谷丰登, 六畜兴旺). The term “six livestock," referring to horse, cattle, sheep/goat, pig, dog, and chicken, originates from Zuo's Commentary on Spring and Autumn Annals (Zuo zhuan 左传), which records in an entry under "The Nineteenth Year of the Reign of Duke Xi" (Xigong shijiunian 僖公十九年, 641 BCE) that “the six livestock were not used together as sacrifices in ancient times" (古者六畜不相为 用). The section on the “Agents for Regional Direction" (Zhi fang shi 职方氏) of the “Summer Ministry" (Xia guan 夏官) in the Rites of the Zhou Dynasty (Zhou li 周礼) also records that “there were six animals suitable for domestication" (其畜宜六扰). In his commentary to this work, Zheng Xuan 郑玄 (127-200) notes that these six animals were horse, cattle, sheep/goat, pig, dog, and chicken. The six livestock were the main domestic animals in ancient China, and this paper first expounds the zooarchaeological methods for identifying animals that have been domesticated, and then discusses their origins.

\section{Methods for identifying domestic animals}

Zooarchaeological studies over the years have confirmed that ascertaining the origins of domestic animals is a rather complicated task (Yuan 2001; Yuan 2002; Yuan and Flad 2002). In order to be able to carry out scientific research and acquire a fairly objective understanding of this issue, it is suggested that we should establish comprehensive methods for identifying domestic animals, using multiple criteria and perspectives.

Through years of research, the author has gradually built up a series of criteria by which to identify domestic animals. Some are based on previous studies by other scholars and some on our own recent studies. They include:

\subsection{Morphological metrics}

Having been domesticated, animals are unable to move freely as they would in the 
wild, and their feeding and other actions are under human control. For those raised to provide meat, in particular, human intervention and the psychological pressures thus incurred often affect their growth and development. Diachronic observations reveal that during the process of domestication some animals have been made smaller, and some larger than their wild ancestors. Therefore, by taking measurements of teeth and specified parts of bones and comparing them with similar wild animals, we can identify domestic animals based on size. This method has been applied in zooarchaeological research in China since the 1970s (Zhou 1981).

\subsection{Pathology}

Pathological symptoms appear in teeth and skeletal elements. Symptoms in teeth include dentition twisting, dental caries, periodontitis and the resulting alveolar abscesses, linear enamel hypoplasia, and bone lesions. Dentition twisting is caused by husbandry. For example, pigs have been reduced in size during domestication, but the physical changes do not occur simultaneously in different parts of the body. Teeth tend to be the last to change, resulting in the fact that as they reduce gradually in size, they must grow out from the much smaller maxilla and mandibular, leading to teeth crowding and malalignment. This method has been employed since the twenty-first century (Yuan 2007, 82-95).

Alveolar abscesses are mainly caused by dental caries and periodontitis, which are directly proportional to the content of sugar or carbohydrates in food. Food rich in starch and sugar can easily lead to dental caries, gingiva inflammation and decay, leaving lesions on bones. This phenomenon was more common among the ancient populations that relied on agriculture rather than on other means of subsistence. In addition, this phenomenon has been found in the remains of domestic pigs at archaeological sites, but not in wild boar. The method has been utilized since the end of the twentieth century (Nishimoto 1999, 59-62).

Linear enamel hypoplasia is a defect of enamel thickness in mammalian crown formation. It typically appears as one or several transverse grooves or lines on the surface of the tooth crown. Since the enamel secretion of ameloblasts is highly sensitive to physiological disturbance, linear enamel hypoplasia is generally incurred by physiological stress during enamel development. The frequency of linear enamel hypoplasia in domestic animals is relatively high, while low in wild animals. This is probably associated with the fact that domestic animals are controlled by humans throughout their lives. This method has been adopted since the twenty-first century (Luo and Yuan 2005).

Bone lesions usually occur on the vertebrae of horses and on the metacarpals and metatarsals of the cattle. They are mostly caused by long-term weighed load and 
traction under control (Rackham 1994, 25).

\subsection{Age structure}

One of the main purposes of animal domestication in ancient times was to supply meat. Generally speaking, domesticated mammals do not grow significantly in size and meat content after reaching a certain age. It is more effective to feed a young animal rather than continuing to rear adult ones. Therefore, if the age of death of a certain mammal in archaeological sites is consistently found to be unnatural, it may be the result of the deliberate slaughter of domestic animals at a specified time. This method has been used in zooarchaeological research in China since the 1960s (Li and Han 1959).

\subsection{Sex ratios}

The sex ratios of domesticated mammals at archaeological sites are usually unbalanced. In the case of pigs, sows or those with characteristics of indeterminate sex generally account for the vast majority of examples, with male pigs being in the minority. However, there are some exceptions where male pigs occupy the majority. It could be speculated that as breeding was artificially controlled, intentional human intervention changed the natural sex ratio of the animal population in ancient times, leading to significant differences between the domesticated and wild populations. This method has been used since the twenty-first century (Yuan 2007, 82-95).

\subsection{Relative proportions}

With regard to the hunter-gatherer subsistence economy, the taxa and relative proportions of species found at archaeological sites largely depend on their natural distribution, how difficult they are to capture, and the indigenous populations' hunting skills. If the skeletal remains of an animal species take up a relatively large proportion of the entire mammalian assemblage in a manner inconsistent with the local wild population, and this proportion increases over time, it is suggestive of the presence of domestication. Take pigs as an example. As the primary purpose of pig domestication was for the supply of meat, the number of domestic pigs should rise high enough to meet the requirements of meat consumption. As pig rearing developed, the number of domestic pigs should show an increasing trend. In such cases, domestic pig bones often constitute quite a large proportion of the animal remains found. Changes in the proportions of bones found should, therefore, be examined chronologically. This method has been used in zooarchaeological research in China since the 1960s (Yuan 2007, 82-95). 


\subsection{Archaeological phenomena}

Archaeological phenomena include buried animals and those used for funerary purposes, or the actual discovery of the pens used for rearing animals. Through many years of research, the author has found that, in Neolithic sites in China, whole pigs, dogs, or some of their limbs, were often buried in pits or tombs. Pigs were the most commonly buried or used as funerary objects, and indeed it could be said that they are ubiquitous across most Neolithic sites in China (Yuan 2009, 175-192). Dogs are found primarily at sites in eastern China (Gao and Shao 2000, 291-303), with fewer examples in northwestern China. In addition to these two types of animals, the author has discovered the phenomenon of the individual burial of complete cattle and sheep/goats during the Late Neolithic. These animals exhibit a continuous relationship to the pigs, dogs, cattle, and sheep/goats found buried in sites of the Xia, Shang, and Zhou dynasties (Yuan et al. 2007, 12-34). Zooarchaeologists have identified more than ten species of mammals unearthed at archaeological sites, however, the animals that have received special handling and been deliberately placed in tombs or special pits were usually confined to dogs, pigs, cattle, sheep/goats, and so forth. Why did ancient people in different regions specifically choose such animals for burial? This may suggest a special connection between them and the animals, one that was developed from the act of rearing. Therefore, the burials of certain animals and the continuity of this practice can be regarded as evidence for domestication. This method has been used since the twenty-first century (Yuan 2007, 82-95).

The remains of animal enclosures also serve as proof of domestication. Such remains have been discovered and studied at the Banpo site in Xi'an, Shaanxi Province, which was excavated in the 1950s (Luo 2009).

\subsection{Diet analysis}

Relying on the fact that the fodder for some domestic animals often includes the stems, leaves, bark, and husks of crops and food waste left over by humans, analysis of, and comparison between, the carbon and nitrogen stable isotopes in animal bones and human bones at the same site can provide scientific evidence for domestication. Since the twenty-first century, a number of Chinese researchers have analyzed carbon and nitrogen stable isotopes from the bones of fish, rats, pigs, cattle, and deer from archaeological sites over a period covering 10,000 years, and thus have gained the carbon and nitrogen stable isotopic signals of various animals from different periods and regions. Based on this, they argue that, in sites of northern China, if the carbon isotope data of pig bones displays a strong signal of $\mathrm{C}_{4}$ plants, consistent with results retrieved from human bones at the same site, it can serve as evidence for pig 
domestication. In the south, however, since rice belongs to the $C_{3}$ category of plants, which predominate in the environment, it is hard to reach a judgment based solely on the carbon isotope results, though comparison between pig and human bones of nutritional levels indicated by nitrogen isotopes can be of value. Research of this kind is undoubtedly a highly useful method for scientifically identifying domestic pigs and wild boar, as well as other domestic animals and wild counterparts (Guan et al. 2008; Guan et al. 2007; Hu et al. 2008; Wu et al. 2007, 49-58).

\subsection{Ancient DNA studies}

Scientists have already acquired a comprehensive understanding of the genetic diversity of living animals, shedding light on the exploration of the genetic characteristics of domestic animals of ancient times. Since the twenty-first century, scientists have progressively identified the relationship between pigs of different regions and periods by examining bones from archaeological sites across the world. This is conducive to establishing the entire pedigree for ancient pigs, identifying domestic pigs and wild boar, and studying the origin of domestic pigs (Larson et al. 2005). Based on DNA studies of ancient sheep and cattle from several sites in China dated to between $4000 \mathrm{BP}$ and $3700 \mathrm{BP}$, the sheep mainly belong to the shared lineages of East and Central Asia, with some also falling within the lineages of West Asia, while the cattle belong primarily to the lineages of West Asia. This serves as invaluable evidence for the origins and emergence of domestic sheep and cattle in China (Cai et al. 2007; Cai et al. 2011a; Cai et al. 2011b, 107-112).

The above interrelated methods are unquestionably significant in determining whether animal bones belong to domestic animals. Among them, one of the most fundamental methods in zooarchaeology is the measurement and observation of unearthed animal bones. However, when discussing the origins of the various domestic animals, if conditions permit, it will be more convincing to first judge from the perspectives of food analysis and archaeological phenomena, and then measure and observe the bones and teeth, produce statistics on the number of animals, and subject all the animal data to zooarchaeological consideration. This is because during the initial period of the domestication of animals it is often difficult to distinguish the animals by their morphological characteristics, and when a wild animal has just transformed into a domestic animal raised by humans, its morphological characteristics will not change immediately, and a transformation process is required. As a result, the measurements may be closer to the data of their wild progenitors rather than domestic animals. In addition, it may be difficult to identify significant changes in terms of quantity and gender. Therefore, various methods, such as measuring and observing animal bones, are extremely effective in determining animals that have undergone domestication for a 
certain period of time, but not for distinguishing animals that have just begun to become livestock. However, after animals have been changed from wild to domestic animals through human intervention, their food habits and possible archaeological phenomena, such as their burial and funerary use, are an important basis on which to make our judgment.

In short, a series of criteria must be adopted for the identification of domestic animals, and the more consistent these research results are, the more objective the conclusions will be.

\section{Origin and emergence of principal domestic animals in China}

No evidence has been found of domestic animals in the early period of the Neolithic in China. The Xianrendong site in Wannian County, Jiangxi Province, and the Yuchanyan site in Dao County, Hunan Province both belong to the early Neolithic, dating back to 12,000 BP. Phytoliths, pottery, stoneware, and bone tools used for cultivating rice have been discovered at these sites (Huang and Chi 1963; Yuan 2000, 31-42). Accordingly, we trace the origin of crop cultivation and pottery making in China back to around $12,000 \mathrm{BP}$. It is worth noting, however, that the species of animals found in these sites are wild animals, and there is no basis on which to prove that domestic animals existed at the time.

According to our research, domestic animals first appeared in China about $10,000 \mathrm{BP}$, nearly 2000 years later than the rise of crop cultivation and pottery. The following domestic animals are discussed in order of appearance.

\subsection{Dog}

DNA analysis on modern dogs reveals that dogs in different regions were all domesticated from wolves (Vilà et al. 1997; Leonard et al. 2002). General belief has it that the dogs found in the Hayonim Terrace cemetery of the Late Natufian culture in northern Israel were the earliest in the world (11,000 BP) (Tchernov and Valla 1997).

Fossils of wolves have been found at many sites in Late Pleistocene China (Qi 1989, 282-307; Han and Xu 1989, 338-391), among which may have been some ancestors of dogs domesticated by ancient peoples. Research conducted so far in China indicates that the dog found at the Nanzhuangtou site (ca. 10,000 BP) in Xushui County, Hebei Province is the earliest domesticated animal in China. There are five main pieces of evidence for this. The first is the change of mandible shape. While the mandibular margin of a wolf is relatively straight, the mandibular margin of the left mandible of the dog from the Nanzhuangtou site is clearly curved (Institute of Archaeology 2010, 30), different from that of a wolf. The second proof can be found in the shortening of the dentition. According to the author's measurements of several wolves housed in the 
Institute of Vertebrate Paleontology and Paleoanthropology, Chinese Academy of Sciences, the length of their mandibular dentition is around $90 \mathrm{~mm}$, while the length of the Nanzhuangtou site dog's mandibular dentition is shorter, only $79.40 \mathrm{~mm}$. The third proof concerns a change in the density of the teeth arrangement. The teeth on the jaws of the Nanzhuangtou site dog are tightly aligned, while those of wolves are relatively spaced out. The fourth line of evidence is the change of mandible size. The size of each measurement point of mandibular specimens from living wolves is significantly larger than that of the similar measurement point on the dog from the Nanzhuangtou site (Yuan and Li 2010). Lastly, comparative study of the measurements of dogs from the Jiahu site provides another line of evidence. The Jiahu site in Wuyang County, Henan Province dates to about $9000 \mathrm{BP}$, around 1000 years later than the Nanzhuangtou site. Eleven dogs were found buried at residential and cemetery locations at the Jiahu site (Zhang 1999, 130). This was a conscious treatment of dogs by people at the time, showing that people and dogs had a special relationship. Measurements of the mandibular of five of the dogs revealed a maximum size of $76.19 \mathrm{~mm}$, and a minimum $68.08 \mathrm{~mm}$, the average being $72.70 \mathrm{~mm}$, and the standard deviation $3.30 \mathrm{~mm}$ (Yuan 2001), which is shorter than those of the specimen at the Nanzhuangtou site. In addition, while the characteristics of the mandibular margin are similar to those of the dog at the Nanzhuangtou site, the overall mandibular shape is smaller. It can be seen that in the course of domestication, dogs gradually evolved to become smaller. The results of the study of the dogs from the Jiahu site provide further corroboration for the Nanzhuangtou site dog.

It should be emphasized here that since the dentition of the dog at the Nanzhuangtou site was significantly shorter than that of wolves, we can surmise that the earliest dogs in China should precede the specimen from the Nanzhuangtou site. Based on research on the mitochondrial DNA of modern dogs, it has been proposed that dogs had already been domesticated in the region south of China's Yangtze River around 16,300 BP (Pang et al. 2009).

Based on the current use of dogs around the world, combined with the conditions of dogs unearthed in archaeological sites, we can speculate that the purpose of dog domestication in ancient times was mainly for hunting, as guard dogs or as pets. Dog domestication can lead to changes in hunting strategies, tactics, and techniques. It neither provided a stable source of meat nor had a significant impact on lifestyle. However, as the earliest domesticated livestock, dogs helped humans to accumulate experience in domestication, laying the foundation for domesticating various other animals. From this point of view, the emergence of dogs is of great significance in the course of human civilization. 


\subsection{Pig}

The ancestors of pigs are wild boars. The research so far by foreign zooarchaeologists reveals that the earliest domesticated pigs in the world were those at the Çayönü site (ca. 9000 BP) in Southeastern Anatolia, Turkey (Hongo and Meadow 1998, 77-98).

Fossils of wild boar have been found at several sites in Late Pleistocene China (Qi 1989, 282-307; Han and Xu 1989, 338-391), and some of their progeny may have been domesticated. The earliest known domestic pigs in China were unearthed at the Jiahu site, Wuyang County, Henan Province (ca. 9000 BP) (Institute of Archaeology 2010, 31). This is supported by seven main pieces of evidence. The first is the abnormal alignment, including twisting, of teeth in the mandible, a fairly typical feature of domestic pigs. Secondly, the relatively high proportion of linear enamel hypoplasia in all molars is within the range of domestic pig populations, and clearly higher than that of wild boar. Thirdly, the tooth shapes indicated by geometric morphometrical studies are similar to those of domestic pigs, but differ greatly from those of wild boar. Fourthly, pigs under the age of two account for $81 \%$ of the total found, and this relatively young age structure is distinct from that of the wild boar population. Fifthly, the proportion of pigs accounts for more than $25 \%$ of the mammals unearthed, far greater than that of the wild boar population in nature. Sixthly, the mandibles of pigs placed in graves as burial accessories are of a kind with those found at numerous sites from subsequent millennia. Seventhly, the analysis of carbon and nitrogen stable isotope points to the pigs having a similar diet to that of humans due to foddering. Based on the afore-mentioned, it can be concluded that there were domestic pigs at the Jiahu site about 9000 BP (Luo and Zhang 2008), roughly the same time as the Çayönü site in Turkey.

In recent years, worldwide DNA research regarding pigs has corroborated the high likelihood that pigs may have been independently domesticated in different regions (Larson et al. 2005). Research in China also supports this finding (Larson et al. 2010). The size of the pigs from the Jiahu site (ca. $9000 \mathrm{BP}$ ) in northern China is similar to those from the Cishan site, Wu'an County, Hebei Province (ca. 8000 BP) in northern China, but differs quite greatly from those found at the Kuahuqiao site, Xiaoshan County, Zhejiang Province (ca. 8200 BP) in southern China (Luo and Zhang 2008). This north-south difference in domestic pig size matches that of the shape of wild boar fossils of the Pleistocene (Luo 2012, 134-142). This leads one to think that, even in China, there may have been multiple domestication centers.

Combining research results concerning Chinese Neolithic cultures and current evidence about the origins of pig domestication and its process of development in various regions over time, it can be inferred that, at least in the Yellow River basin, the stability and continuation of settlement life gradually made cultivated crops the staple food, resulting in population increase. In addition, long-term hunting led to a 
continuous decline of wildlife around settlements, resulting in the failure of hunting to provide adequate meat resources to sustain the population. Therefore, it is believed that pigs were domesticated to ensure a stable supply of meat. Our research has also made us aware, however, of the phenomenon of the discover of domestic pigs at sites (ca. $8000 \mathrm{BP}$ ) in the Yangtze River valley, and that continuous pig domestication is evident at many sites dating to after $8000 \mathrm{BP}$, yet, for a considerable period of time, domestic pigs do not appear to have increased in number. Therefore, while judging that pig-raising at that time was related to meat eating, we should also explore the reasons for raising domestic pigs from another angle. Since pigs were buried or used as funerary accessories in these areas over a relatively long period of time, demands of the spiritual realm may also be one of the reasons for pig domestication at that time.

The significance of the emergence of domestic pigs is great. For thousands of years, there has been no other domestic animal like pigs, which play a crucial role both as the principal meat supply for the Chinese people, as well as playing an important role in the spiritual realm. Historically, pig rearing techniques spread throughout East Asia, boosting the economic and cultural life of human society.

\subsection{Sheep and goats}

Given the lack of systematic study on sheep and goats in Chinese zooarchaeology and the general designation of sheep and goats as ovicaprids, they are explored together in this article.

One view has it that sheep may have been domesticated from extinct mouflon or argali, and goats from wild goats (Tong 2004). Extant studies show that sheep and goats were first domesticated in Zagros and its environs, southwestern Iran (ca. 10,000 BP) (Zeder and Hesse 2000). DNA research suggests that goats may derive from one single origin (MacHugh and Bradley 2001), while sheep have multiple origins (Cai et al. 2007).

According to previous research, fossils of sheep, argali, goats, and caprine have been excavated from several sites of the Late Pleistocene in southern and northern China (Qi 1989, 282-307; Han and Xu 1989, 338-391). However, for quite a long time after entering the Holocene, despite the discovery of relics of various animals in many sites, no well-documented sheep bones have been found.

In the 1970s, while archaeologists were excavating graves dating to ca. 5600-5000 BP in Gansu and Qinghai Provinces, caprine bones were discovered as burial accessories. However, only excavation records were made at the time, and the bones themselves were not kept. Therefore, there is no way to conduct zooarchaeological research on them. Based on the information available, the author cannot yet undertake a comprehensive and scientific discussion of the earliest sheep. Be that as it may, this author thinks that the earliest domestic sheep in China appeared all of a sudden in 
Gansu and Qinghai Provinces about 5600-5000 BP, then spread eastward, entering into the Central Plains around $4500 \mathrm{BP}$. There are seven reasons for this.

First and foremost, sheep have been discovered in northwestern China about 5000 BP or earlier, sheep mandibles having been found in a tomb belonging to the Shilingxia type of the Majiayao culture (ca. 5600-5000 BP) at the Shizhaocun site (tomb M5), Tianshui, Gansu Province (Institute of Archaeology 1999, 53). A burial accessory of a complete ovicaprid skeleton was uncovered in a tomb of the Majiayao type of the Majiayao culture at the Hetaozhuang site, Minhe County, Qinghai Province (Qinghai Provincial Archaeological Team 1979). Although we now have no way to identify whether the bones from the Shizhaocun and Hetaozhuang sites belong to sheep or goats, the author surmises that they should be sheep, considering that bones from many later sites all belong to sheep, and the earliest known goats in the Central Plains were found at the Erlitou site (ca. 3700 BP), Yanshi County, Henan Province (Yang 2008, 470-539).

The second is the fact that sheep have been discovered in the Central Plains (over 4000 BP). Sheep bones have been found at many sites, such as the Taosi site, Xiangfen, Shanxi Province, the Wangchenggang site, Dengfeng, and the Longshan cultural layer of the Wadian site, Yuzhou, Henan Province (all ca. 4500-4000 BP). Nonetheless, caprine bones are rarely found in pre-Longshan culture sites of the Central Plains, but appear in all sites thereafter. Diachronically speaking, the emergence of sheep has an obvious process of development from none to some and a few to many (Yuan et al. 2007, 12-34; Lü, Yang, and Yuan 2007, 815-901). Moreover, sheep bones have been found in the following sites in Gansu Province (ca. 4000 BP): the Qijia cultural layer of the Shizhaocun site, Tianshui (Zhou 1999, 335-339); the Qijia culture tombs of the Dahezhuang site (Gansu Archaeological Team 1974), and the Qinweijia site (Gansu Archaeological Team 1975), Yongjing County; and the Siba culture site at Donghuishan, Minle County (Qi 1998, 184-185). Given that sheep have been found in many sites (ca. $5000 \mathrm{BP}-4000 \mathrm{BP}$ ) in the Gansu-Qinghai area, we speculate that sheep remains could also be unearthed from sites dating from between 5000 BP to 4000 BP there. Pertinent research would play a key role in bridging the gap in this period and explicating the spread of domestic sheep to the Central Plains.

The third line of evidence lies in measurement data. Measurement of sheep bones from Longshan culture sites in the Central Plains reveal that they are relatively similar in size, and are very close to the measurements of domestic sheep of the Shang and Zhou dynasties.

The fourth is the special phenomenon of burying sheep. At two Longshan culture sites, the Baiying site in Tangyin County, Henan Province, and the Dongxiafeng site in Xia County, Shanxi Province, sheep were found that had been individually trussed up and buried (Anyang Committee of Cultural Relics Management 1980; Dongxiafeng 
Archaeological Team 1983). Furthermore, sheep scapulae have been found the Qijia culture site of Dahezhuang, Yonging County, Gansu Province with traces of scorching on them indicative of a form of ancient divination (Gansu Archaeological Team 1974).

The fifth is the development of secondary products from sheep, with evidence of sheep shearing having been found at the Taosi site, Xiangfen, Shanxi Province (ca. 4000 BP) (Bo 2011).

The sixth is the result of the analysis of ancient DNA. Based on the sudden appearance of domestic sheep and DNA analysis of sheep at several sites, lineage A predominated among sheep at that time, and this lineage is now is mainly located in Central and East Asia. Moreover, a sheep lineage B still exists, and there are still sheep of this linage in Western Asia and Europe (Cai et al. 2007; Cai et al. 2011b). It is thus speculated that domestic sheep in China were introduced from outside through cultural exchange, while the origins or emergence of goats remain to be studied.

The seventh is the result of carbon and nitrogen stable isotope analysis. These findings suggest that sheep from the upper and middle reaches of the Yellow River mainly contained $C_{3}$ plants and a small proportion of $C_{4}$ plants. Since the contribution of $\mathrm{C}_{4}$ plants in natural vegetation is negligible in areas with an annual average temperature of below $15^{\circ} \mathrm{C}$, these plants in the sheep's diet may have come from the use of such $\mathrm{C}_{4}$ crops as millet straw in fodder (Chen et al. 2012). The feeding habits of sheep remained this way from the Longshan period to the Erlitou period, which also reflects the stability of the way humans raised sheep for a long time.

Although the earliest sheep bones found to date were found as burial accessories, it cannot be concluded that demands of the spiritual realm were the main driving force for their emergence, due to there being no participation by zooarchaeologists in their excavation and research. Based on current zooarchaeological studies, we ascribe the emergence of sheep domestication to the provision of meat, the satisfaction of ritual activities, and for obtaining such secondary products as wool. This may be related to the fact that sheep came from areas outside China where they were already domesticated, and several purposes for raising sheep that were formed at that time may have been introduced into China with the sheep.

Domestic sheep and goats not only provide meat and dairy products, but also held an important position in ancient sacrificial activities. Additionally, their wool supplies the raw material for clothing to guard against cold. The acquisition and weaving of wool also gave a boost to the development of specialized handicrafts.

\subsection{Cattle and buffalo}

In view of the facts that buffalo have been rarely discussed in the context of the zooarchaeology of China, and that cattle and buffalo are sometimes collectively 
referred to as cattle, they both are examined here together.

Zooarchaeological and DNA research have demonstrated that cattle were domesticated from local bison in Western Asia and northeastern Africa (ca. 10,000 BP) (Bradley et al. 1998; Marshall and Hildebrand 2002). It has also been proposed that cattle were domesticated independently in India around the same time (Loftus et al. 1994), while domestic cattle already existed in northwestern South Asia ca. 7500 BP (Meadow 1996, 390-412). The earliest evidence for buffalo domestication comes from the Indus River basin (ca. 5000 BP) (Patel and Meadow 1998, 180-198).

Fossils of wild cattle have been found at many Late Pleistocene China sites (Qi 1989, 282-307; Han and Xu 1989, 338-391). Cattle bones have been discovered in varying quantities at sites of all periods since the Holocene, however, since site reports frequently lack details about such bones, it is still difficult to determine the time and place of the origin of domestic cattle with reasonable precision. Current research dates domestic cattle in the middle and lower reaches of the Yellow River to the end of the Late Neolithic period, at least 4500-4000 BP. These include such sites as Taosi in Xiangfen County, Shanxi Province, Pingliangtai in Huaiyang County, Guchengzhai in Xinmi County, Wadian in Yuzhou, and Shantaisi in Zhecheng County, Henan Province. There are six main lines of evidence, as follows.

The first is morphological characteristics. The cattle bones from the above sites on the whole are slender, similar to those of domestic cattle from Shang and Zhou dynasty sites. The second is measurement data. Bones from these sites were of the same size as those of the Shang and Zhou dynasties. The third is changes in quantity. The number of cattle remains from these sites and their proportion of all mammals found have reached a certain degree, especially at sites with several cultural layers of different periods, with the quantity of cattle bones found in each cultural layer gradually increasing over time. The fourth is the discovery of the special burial of cattle. Nine head of cattle were collectively buried in a regularly placed fashion in the Longshan culture site of Shantaisi, Zhecheng County, Henan Province (ca. 4500-4000 BP) (Zhang and Zhang 1997), while individually buried cattle have been found at the Longshan culture site of Pingliangtai in Huaiyang County, Henan Province. Cattle burials became progressively more common in the Xia, Shang, and Zhou dynasties (Yuan et al. 2007, 12-34; Lü 2010, 152-176). The fifth is analysis results from ancient DNA. DNA analysis of cattle bones from the Changning site in Datong County, Qinghai Province (ca. 4000 BP) show that they belong to the cattle lineage T3 in West Asia (Cai et al. 2011a), providing a scientific basis for our discussions on the origins of cattle. The sixth is carbon and nitrogen stable isotope analysis. Analysis of cattle bones from several sites in the middle and lower reaches of the Yellow River shows that from the Longshan period to the Erlitou period, $\mathrm{C}_{4}$ plants developed from comprising the main part to the whole of the diet of cattle (Atahan et al. 2011; Chen et al. 2012). In areas where the average annual temperature is 
below $15^{\circ} \mathrm{C}$, the contribution of $\mathrm{C}_{4}$ plants in natural vegetation is negligible, so the $\mathrm{C}_{4}$ plants appearing in the diet of cattle can be considered to be the result of their fodder containing such $\mathrm{C}_{4}$ type crops as millet straw. This development in the proportion of $\mathrm{C}_{4}$ plants reflects the progress of cattle domestication.

To date, cattle remains have been found in Gansu Province at the Shizhaocun and Xishanping sites in Tianshui, the Fujiamen site in Wushan County, and the Xishan site in Li County. Among these, at the Shizhaocun and Xishanping sites, cattle remains first appear in the Majiayao cultural layer, and have been unearthed in all later layers. At the Fujiamen site, bones used for divination made of cattle scapulae were found from the Majiayao cultural period. In the late Yangshao culture site of Xishan, the measurement data and ratios of cattle remains conform to standard data for domestic cattle. This evidence suggests that the Gansu-Qinghai area should be the first place where cattle domestication occurred in China during the Majiayao type period of Majiayao culture at least 5000 BP (Lü, Yuan, and Li 2014).

Based on the broken bones of cattle and buried complete skeletons that have been found at sites, the author speculates that the purposes of raising cattle were probably to obtain meat and for spiritual reasons. However, there is no evidence for the use of cattle as animal labor. Zooarchaeological research conducted abroad indicates that the overuse of domestic animals tends to lead to bone hyperplasia and other pathological bone changes. Hyperplasia of the distal metacarpal and phalangeal bones of cattle at the late Shang dynasty Yinxu site in Anyang, Henan Province is the earliest example found to date. ${ }^{2}$ Nonetheless, further study is required to determine whether this bone hyperplasia resulted from overwork, and whether cattle were actually used for ploughing or transport in the late Shang dynasty. There is a record of cattle being used for ploughing in The Analects of Confucius (Lunyu 论语): “The calves of plowing cattle have reddish fur and regular horns. Although (we) do not want to use them for sacrifice, will the (gods of) mountains and rivers allow?" (Confucius 2009, 56). ${ }^{3}$ The term lijiu 犁牛 here means plowing cattle. Actual events usually precede written records, so it seems justifiable that ploughing with cattle already existed before the Spring and Autumn period.

The origin of domestic buffalo remains obscure. According to some researchers there are distinct morphological and genetic differences between living domestic buffalo and the short-horned water buffalo (Bubalus mephistopheles) of the China's Neolithic and Shang periods. The latter were never domesticated and became extinct. Living domestic buffalo are likely to have been introduced from South Asia, no earlier than 3000 BP (Liu, Chen, and Yang 2006). Whether this inference is correct remains to

2 As informed by Li Zhipeng 李志鹏, Institute of Archaeology, Chinese Academy of Social Sciences.

3 “犁牛之子骍且角, 虽欲勿用, 山川其舍诸? ” 
be confirmed.

In addition to diversifying sources of meat for humans and playing an important role in ritual activities, domestic cattle were of greatest importance in ploughing, for which they were widely used in historical times. Cattle ploughing greatly improved agricultural labor productivity, driving the development of the agricultural economy in ancient times, marking an epoch-making advance in the history of agriculture in China.

\subsection{Horse}

The theory that horses were domesticated from wild breeds in Central Asia ca. 5500 BP remains controversial (Brown and Anthony 1998; Levine 1999; Cai et al. 2009).

Fossils of Przewalskii wild horses have been found in many Late Pleistocene sites in northern China (Cai 1989, 282-307). According to the latest DNA analysis, early domesticated horses in China did not originate from the Przewalskii breed (Cai et al. 2009). After entering the Holocene, a variety of animal remains have been unearthed in many sites and carbon-14 dated, but horse bones have basically not been found among them.

Three horse mandibles were excavated at the Qijia culture site of Dahezhuang (ca. 4000-3600 BP) (Gansu Archaeological Team 1974), and horse bones were found at the Qijia culture site of Qinweijia in Yongjing, Gansu Province (Gansu Archaeological Team 1975). Horse bones probably related to sacrificial rituals were uncovered at the Huoshaogou site, Yumen, Gansu Province (later than 3700 BP) (Gansu Provincial Museum 1979, 139-153). However, these horse bones have not been measured, inspected, and investigated scientifically, there being only brief written records of their excavation. Discoveries at the Dahezhuang and Qinweijia sites indicate that horse domestication had already taken place in the Gansu-Qinghai region of China ca. 4000-3600 BP.

According to the author's research to date, in the middle and lower reaches of the Yellow River at least, domestic horses existed no earlier than the late Shang dynasty (ca. 3300 BP). This can be attested to by the fact that large quantities of fauna bones have found at early Shang sites, such as the Shang city site in Yanshi, the Shang city site and the Xiaoshuangqiao site in Zhengzhou, Henan Province, but there is no evidence of horse bones. In the Neolithic, although many sites have produced faunal remains, horse bones have been found at relatively few, and problems with their chronology and stratigraphy remain to be clarified (Yuan 2003, 436-443). Multiple pits containing chariots and horses have been found in the late Shang Yinxu site (ca. 3300 BP), Anyang, Henan Province (Institute of Archaeology 1998, 8-9), one chariot in general accompanied by two horses. Elsewhere, over one hundred horse pits were unearthed at the Yinxu Xibeigang site (Anyang Archaeological Team 1987), each pit containing 
between one to thirty-seven horses, two being the most common. These horse burials most likely were related to sacrifice. Pits of chariot and horses have also been found at the late Shang Laoniupo site in Xi'an, Shaanxi Province, and the late Shang and early Zhou Qianzhangda site in Tengzhou, Shandong Province. These data testify to the presence of horse domestication in the middle and lower reaches of the Yellow River ca. $3300 \mathrm{BP}$.

Significant progress has been made in zooarchaeological research on the horse bones found at Yinxu. Morphological observation and measurement, pathological observation, quantitative analysis, archaeological and cultural observation, ancient DNA analysis, and carbon and nitrogen stable isotope analysis not only prove that these horses were domesticated, but also provide a solid basis on which to trace back earlier horses (Liu 2013, 78-87). This paper will not dwell on these unpublished research results here. Given that few horse bones have been discovered in that area before $3300 \mathrm{BP}$, and that horse and chariot pits with buried horses appeared in many sites after $3300 \mathrm{BP}$, the author holds that domestic horses appeared there suddenly (Yuan and Flad 2006, 124-131).

With regard to the route(s) by which horses were introduced into the Central Plains, the Gansu-Qinghai region could be one option (Flad, Yuan, and Li 2009), and the north-south route from the Inner Mongolia region another. It should be emphasized that, even in the Gansu-Qinghai region, domestic horses appeared more than 1500 years later than the earliest known in the world, most likely introduced from the steppes of Central Asia.

The domestic horses found in the chariot and horse pits at Yinxu were directly connected to the use of chariots. Thus, pulling chariots should be one of the reasons for horse domestication. In addition, hundreds of buried horses were found in a large number of pits at the Xibeigang site at Yinxu, which falls within the range of a royal mausoleum, indicating that large-scale horse burial was a symbol of royal power. From this point of view, horse domestication seems to have had the function of consolidating the hierarchical system. Foreign scholars have found that horse riding results in pathological changes to certain parts of the horse, such as the thoracic vertebra (Levine, Whitwell, and Jeffcott 2005), and there are no signs of such changes on the horse skeletons found at Yinxu. Thus, we may speculate that horse riding was not practiced at the time, and that it was not the reason for domesticating horses at that time.

Domestic horses not only provide meat and serve ritual purposes, but also greatly enhance transportation capacity, with war horses, in particular, playing a significant role in warfare, facilitating human migration, national integration, language and cultural transmission, and social progress. 


\subsection{Chicken}

Domestic chickens originated from the red junglefowl (Zhou 1981), but the question of when this occurred has still not been precisely answered by the international zooarchaeological community.

In the late 1980s, British and Chinese scholars co-authored a paper pointing out the presence of domesticated chickens in the Cishan site at Wu'an, Hebei Province (ca. $8000 \mathrm{BP}$ ), based on the evidence of the metatarsus bones of the chickens measuring roughly the same size as those of junglefowl. In addition, the majority of the unearthed bones belong to males, perhaps due to human factors (West and Zhou 1988). American scholars think that these are the earliest known domesticated chickens worldwide (Reitz and Wing 2008, 292). This author feels that the lack of a scientifically defined range of size differences in metatarsus bones between chickens and pheasants renders it hard to make scientific judgments based solely on the measurement of such bones, while incidentally discarded chicken bones and the limited excavation range imposed at the time may affect the statistical results of unearthed bones. Therefore, it is not possible to judge that domestic chickens existed at that time.

More importantly, the author's own observations found that several "chickens" metatarsus bones from the Cishan site exhibited at Handan Museum, Hebei Province belong to pheasants rather than chickens. Although both chickens and pheasants are within the Phasianidae family, they belong to two different genera and two different species. Pheasants have remained as pheasants until the present day, but domestic chickens are domesticated from the red junglefowl. The two should not be confused.

In the Introduction, we mentioned a textual reference to six livestock, which included chickens, in 641 BCE. After re-examining and verifying chicken-related bone data unearthed from thirty-six sites dating to before $641 \mathrm{BCE}$, we found that most judgments lacked a basis in zooarchaeology. This includes some simple conclusions based on lack of identification, and some based on speculation that because domestic chickens already existed in earlier sites, those found in slightly later sites should also be. It should be noted that some of the judgments are clearly wrong (Deng et al. 2013). For example, some scholars believe that domestic chickens already existed about $7000 \mathrm{BP}$ based on the discovery of the relatively complete "chicken bone" found in a pottery pot at the Beishouling site in Baoji, Shaanxi Province (Zhou 1983, 145-153). Some scholars also consider that "chicken bones" have been found at the Dawenkou cemetery site in Tai'an, Shandong Province (ca. 5500-4600 BP) (Li 1974, 156-158). However, the published photos of these so-called "chicken" metatarsus bones reveal that they belong to pheasants rather than chickens. If we take the metatarsus bones of modern pheasants and chickens, and compare those of pheasants from the Beishouling site and the Dawenkou cemetery site and those of chickens from the Han Shenmingpu site in 
Xichuan, Henan Province, the shape of both the proximal and distal ends of the metatarsus bones display clear differences. In addition, "pottery chicken" have been found at some Neolithic sites in China, such as the Shijiahe site cluster in Shimen, Hubei Province (Shijiahe Archaeological Team 1999, 215-217). Further discussion is required as to whether these bird-like pottery wares represent domestic chickens. As far as zooarchaeology is concerned, chicken identification should be premised on chicken bones from archaeological sites, and artifacts can only act as supplementary evidence.

According to research to date, domestic chickens existed at the Yinxu site at Anyang, Henan Province (ca. 3300 BP) (Deng et al. 2013). The first piece of evidence for this lies in morphological characteristics. An incomplete chicken skull from Xiaotun pit no. 1 was analyzed morphologically in detail, and such features as the small occipital condyle, deep and large fossa subcondylaris, and highly developed external ophthalmic canal and vagus nerve foramen were noted. These point to a domestic chicken (Hou 1989). The second line of evidence relies on oracle-bone inscriptions, with inscriptions found at Yinxu showing striking differences between the characters $j i$ 鸡 (chicken) and zhi 雉 (pheasant) (Guo 1979a, 1585; Guo 1979b, 2458). According to Yan Zhibin 严志斌, $j i$ generally refers to names of sacrifices or places for hunting, while zhi is used as a verb as well as for names of birds and places. It is noteworthy that sacrificial animals mentioned in the Yinxu oracle-bone inscriptions were in general domestic animals. ${ }^{4}$

Given that few chicken bones are found at archaeological sites, the explanation for raising chicken just for meat seems inadequate. Perhaps obtaining their eggs is another reason, though due to a lack of evidence this requires verification. Ancient written records on the relationship between chicken domestication and crowing offer another possible explanation. In summary, such discussions are open to further study.

\section{Conclusion}

Zooarchaeological studies to date provide the appearance times, locations, and species for the six main domestic animals in China as follows: Dogs appeared in southern Hebei Province ca. 10,000 BP, pigs in southern Henan Province ca. 9000 BP, sheep/goat in the Gansu-Qinghai region ca. 5600-5000 BP, cattle in eastern Gansu Province ca. 5000 BP, horses in eastern Gansu Province ca. 4000-3600 BP, and chickens in eastern Henan Province ca. 3300 BP. These domestic animals originated or appeared at different times and places, though basically all in northern China.

It must be pointed out that the judgment that domestic sheep and horses first appeared in the Gansu-Qinghai region is derived from the results of archaeological

4 As informed by Yan Zhibin, Institute of Archaeology, CASS. 
research, using only one line of evidence to identify domestication. In the absence of the original artifacts, we can no longer conduct zooarchaeological research on animal remains excavated decades ago. With the progress of archaeological excavations in the future and further scientificization of research methods, our understanding of the times of the emergence, locations, and species of the main domestic animals in China will be further corrected, supplemented and refined.

Nevertheless, no matter how comprehensive future research proves to be, according to the data available at present, the origins and emergence of domestic animals can be roughly analyzed using two models. On the one hand, in the course of dealing with some wild animals, ancient inhabitants gradually controlled them according to their own needs, and domesticated them into livestock, for instance dogs and pigs. On the other hand, they introduced such livestock as horses, cattle, and sheep/goat directly from other areas through cultural interaction.

Bones of the above-mentioned animals are mostly fragmented, and can be regarded as post-consumption refuse. Hence, the main reason for livestock domestication was a steady meat supply. Further research on related animal remains at more sites is still required to draw more scientific conclusions on a number of issues, such as the role of domestication in hunting, ritual activities, the consolidation of ruling systems, servitude, and secondary product development.

\section{References}

Anyang Archaeological Team, Institute of Archaeology, CASS. 1987. “Anyang Wuguancun Beidi Shangdai jisikeng de fajue” 安阳武官村北地商代祭祀坑的发掘 [Excavation of the Shang Sacrificial Pits in Northern Wuguan Village, Anyang]. Kaogu 考古 [Archaeology], no. 12, 1062-1070.

Anyang Committee of Cultural Relics Management. 1980. “Henan Tangyin Baiying Longshan wenhua yizhi” 河南汤阴白营龙山文化遗址 [The Longshan Culture Site at Baiying, Tangyin, Henan Province]. Kaogu, no. 3, 193-202, 289.

Atahan, P., Dodson J., Li X., Zhou X., Hu S., Bertuch F., and Sun N. 2011. “Subsistence and the isotopic signature of herding in the Bronze Age Hexi Corridor, NW Gansu, China." Journal of Archaeological Science 38 (7): 1747-1753.

Bo, Kailing 博凯龄. 2011. “Zhongguo Xinshiqi Shidai wanqi dongwu liyong de bianhua ge'an tanjiu” 中国新石器时代晚期动物利用的变化个案探究 [A Case Study of Changes in Animal Utilization in Late Neolithic China]. In Sandai kaogu 三代考古 [Archaeology of the Xia, Shang, and Zhou Dynasties], edited by Department of Xia, Shang and Zhou Archaeology, Institute of Archaeology, CASS, 4:129-182. Beijing: Science Press.

Bradley, D. G., R. T. Loftus, P. Cunningham, and D. E. MacHugh. 1998. “Genetics and domestic cattle origins." Evolutionary Anthropology 6 (3): 79-86.

Brown, D., and D. Anthony. 1998. "Bit wear, horseback riding and the Botai site in Kazakstan." Journal of Archaeological Science 25 (4): 331-347.

Cai, Dawei 蔡大伟, Han Lu, Zhang Xiaolei, Zhou Hui, and Zhu Hong. 2007. “DNA analysis of 
archaeological sheep remains from China." Journal of Archaeological Science 34 (9): 1347-1355. Cai, D., Tang Z., Han L., C. F. Speller, Yang D. Y., Ma X., Cao J., Zhu H., and Zhou H. 2009. "Ancient DNA provides new insights into the origin of the Chinese domestic horse." Journal of Archaeological Science 36 (3): 835-842.

Cai, Dawei, Tang Zhuowei 汤卓炜, Ren Xiaoyan 任晓燕, Idris Abdurusul 依地利斯 - 阿不都热 苏勒, Yu Huixin 于慧金金, Zhou Hui 周慧, and Zhu Hong 朱泓. 2011a. “Zhongguo beifang diqu sange Qingtong Shidai yizhi huangniu yihai fenzi kaoguxue yanjiu” 中国北方地区三个青铜时 代遗址黄牛遗骸分子考古学研究 [Molecular Archaeological Study on the Cattle Remains from Three Bronze-Age Sites in Northern China]. In Keji kaogu 科技考古 [Science for Archaeology], edited by the Center for Scientific Archaeology, Institute of Archaeology, CASS, 3:106-111. Beijing: Science Press.

Cai, Dawei, Tang Zhuowei, Ren Xiaoyan, Wang Lixin 王立新, Yu Huixin, Zhou Hui, and Zhu Hong. 2011b. “Qinghai Datong Changning he Neimenggu Chifeng Dashanqian yizhi Qingtong Shidai gumianyang fenzi kaoguxue yanjiu” 青海大通长宁和内蒙古赤峰大山前遗址青铜时代古 绵羊分子考古学研究 [Molecular Archaeological Study on the Bronze-Age Ancient Sheep from Changning, Datong, Qinghai and the Dashanqian Site in Chifeng, Inner Mongolia]. In of Keji kaogu, edited by the Center for Scientific Archaeology, Institute of Archaeology, CASS, 3:107-112. Beijing: Science Press.

Chen, Xianglong 陈相龙, Yuan Jing 袁靖, Hu Yaowu 胡耀武, $\mathrm{He} \mathrm{Nu}$ 何努, and Wang Changsui 王昌燧. 2012. “Taosi yizhi jiachu siyang celüe chutan: laizi tan dan wending tongweisu de zhengju” 陶寺遗址家畜饲养策略初探: 来自碳、氮稳定同位素的证据 [On the Feeding Strategies of Livestock at the Taosi Site: Evidence from Carbon and Nitrogen Stable Isotope Analyses]. Kaogu, no. 9, 75-82.

Confucius. 2009. Lunyu yizhu 论语译注 [Translation and Annotation of The Analects of Confucius], translated and annotated by Yang Bojun 杨伯峻. Beijing: Zhonghua Book Company.

Deng, Hui 邓惠, Yuan Jing, Song Guoding, Wang Changsui, and Eda Masaki. 2013. “Zhongguo gudai jiaji de zai tantao" 中国古代家鸡的再探讨 [Revisiting Domestic Chickens in Ancient China]. Kaogu, no. 6, 83-96.

Dongxiafeng Archaeological Team of Institute of Archaeology, CASS, the National Museum of Chinese History, and CPAM of Shanxi Province. 1983. "Shanxi Xiaxian Dongxiafeng Longshan Wenhua yizhi" 山西夏县东下冯龙山文化遗址 [The Longshan Culture Site at Dongxiafeng in Xia County, Shanxi Province]. Kaogu xuebao 考古学报 [Acta Archaeologica Sinica], no. 1, 55-92, 133-142.

Flad, Rowan K. 傅罗文, Yuan Jing, and Li Shuicheng 李水城. 2009. “Lun Zhongguo Ganqing diqu Xinshiqi Shidai jiayang dongwu de laiyuan ji tezheng” 论中国甘青地区新石器时代家养动 物的来源及特征 [On the Source and Features of Neolithic Domestic Animals in the Gansu and Qinghai Region, China]. Kaogu, no. 5, 80-86.

Gansu Archaeological Team, Institute of Archaeology, CAS. 1974. “Gansu Yongjing Dahezhuang yizhi fajue baogao" 甘肃永靖大何庄遗址发掘报告 [Excavation Report of the Dahezhuang Site, Yongjing, Gansu Province]. Kaogu xuebao, no. 2, 29-61.

Gansu Archaeological Team, Institute of Archaeology, CAS. 1975. “Gansu Yongjingxian Qinweijia Qijia Wenhua mudi” 甘肃永靖县秦魏家齐家文化墓地 [The Qijia Culture Qinweijia 
Cemetery in Yonging County, Gansu Province]. Kaogu xuebao, no. 2, 57-96.

Gansu Provincial Museum. 1979. “Gansusheng wenwu kaogu gongzuo sanshinian” 甘肃省文物 考古工作三十年 [Three Decades of Undertakings in Cultural Relics and Archaeology in Gansu Province]. In Wenwu kaogu gongzuo sanshinian 文物考古工作三十年 [Three Decades of Undertakings in Cultural Relics and Archaeology], edited by the Editorial Board of Cultural Relics, 139-153. Beijing: Cultural Relics Press.

Gao, Guangren 高广仁, and Shao Wangping 邵望平. 2000. “Zhongguo shiqian shidai de guiling yu quansheng" 中国史前时代的龟灵与犬牲 [Tortoise Divination and Dog Sacrifice in Prehistoric China]. In Haidai qu Xianqin kaogu lunji 海岱区先秦考古论集 [Collection on Archaeology of the Pre-Qin Haidai Region], edited by Gao Guangren, 291-303. Beijing: Science Press.

Guan, Li 管理, Hu Yaowu 胡耀武, Hu Songmei 胡松梅, et al. 2008. “Shaanbei Jingbian Wuzhuangguoliang dongwugu de C he $\mathrm{N}$ wending tongweisu fenxi” 陕北靖边五庄果墚动物骨的 $\mathrm{C}$ 和 $\mathrm{N}$ 稳定同位素分析 [Stable Isotopic Analysis of Animal Bones from the Wuzhuangguoliang Site, Jingbian, Northern Shaanxi]. Disiji yanjiu 第四纪研究 [Quaternary Sciences] 28 (6): 1148-1153.

Guan, Li, Hu Yaowu, Tang Zhuowei, et al. 2007. “Tonghua Wanfabozi yizhi zhugu de C, N wending tongweisu fenxi” 通化万发拨子遗址猪骨的 C, N 稳定同位素分析 [Stable Isotopic Analysis of Pig Bones from the Wanfabozi Site, Tonghua]. Kexue tongbao 科学通报 [Chinese Science Bulletin] 52 (14): 1678-1680.

Guo, Moruo 郭沫若, ed. 1979a. Vol. 4 of Jiaguwen heji 甲骨文合集 [Collections of Oracle-Bone Inscriptions], edited by Institute of History, CASS. Beijing: Zhonghua Book Company.

Guo, Moruo, ed. 1979b. Vol. 6 of Jiaguwen heji, edited by Institute of History, CASS. Beijing: Zhonghua Book Company.

Han, Defen 韩德芬, and Xu Chunhua 许春华. 1989. “Zhongguo nanfang Disiji buru dongwuqun jianlun yuanshi renlei de shenghuo huanjing” 中国南方第四纪哺乳动物群兼论原始人类的生活 环境 [Quaternary Mammalian Fauna in Southern China and the Living Conditions of Primitive People]. In Zhongguo yuangu renlei 中国远古人类 [Ancient Chinese People], edited by Wu Rukang 吴汝康, Wu Xinzhi 吴新智, and Zhang Senshui 张森水, 338-391. Beijing: Science Press.

Hongo, H., and R. Meadow. 1998. "Pig exploitation at Neolithic Çayönü Tepesi (Southeastern Anatolia)." In Ancestor for the Pigs: Pigs in Prehistory, edited by Sarah M. Nelson, 77-98. Masca Research Papers in Science and Archaeology, Book 15. Philadelphia: University of Pennsylvania Museum of Archaeology and Anthropology.

Hou, Lianhai 侯连海. 1989. “Ji Anyang Yinxu zaoqi de niaolei” 记安阳殷墟早期的鸟类 [On Early Birds at Yinxu, Anyang]. Kaogu, no. 10, 942-947.

$\mathrm{Hu}$, Yaowu, Luan Fengshi 亱丰实, Wang Shougong 王守功, et al. 2008. “Liyong C, N wending tongweisu fenxifa jianbie jiazhu yu yezhu de chubu changshi” 利用 C, N 稳定同位素分析法鉴 别家猪与野猪的初步尝试 [A Preliminary Attempt to Identify Pigs and Boars through Stable Isotopic Analysis]. Zhongguo kexue D ji 中国科学 (D 辑): 地球科学 [Science in China (Series D): Earth Sciences] 38 (6): 693-700.

Huang, Wan-po 黄万波, and Chi Hung-giang 计宏祥. 1963. “Jiangxi Wannian Xianrendong Quanxinshi dongxue duiji” 江西万年仙人洞全新世洞穴堆积 [Note on Holocene Hsienjen Cave Deposit of Wannian, Kiangsi]. Gujizhui dongwu yu gurenlei 古脊椎动物与古人类 [Vertebrata 
PalAsiatica] 7 (3): 226-271.

Institute of Archaeology, CASS, ed. 1998. Anyang Yinxu Guojiazhuang Shangdai muzang 安阳殷墟 郭家庄商代墓葬 [The Yinxu Shang Tombs at Guojiazhuang, Anyang]. Beijing: Encyclopedia of China Publishing House.

Institute of Archaeology, CASS, ed. 1999. Shizhaocun yu Xishanping 师赵村与西山坪 [Shizhaocun and Xishanping]. Beijing: Encyclopedia of China Publishing House.

Institute of Archaeology, CASS, ed. 2010. Kaogu Zhonghua 考古中华 [Archaeology in China]. Beijing: Science Press.

Larson, G., K. Dobney, U. Albarella, M. Fang, E. Matisoo-Smith, J. Robins, S. Lowden, et al. 2005. "Worldwide phylogeography of wild boar reveals multiple centers of pig domestication." Science 307 (5715): 1618-1621.

Larson, G., Liu R., Zhao X., Yuan J., D. Fuller, L. Barton, K. Dobney, Fan Q., Gu Z., Liu X., Luo Y., Lü P., L. Andersson, and Li N. 2010. "Patterns of East Asian pig domestication, migration, and turnover revealed by modern and ancient DNA." Proceedings of the National Academy of Sciences of the United States of America 107 (17): 7686-7691.

Leonard, J. A., R. K. Wayne, J. Wheeler, R. Valadez, S. Guillén, and C. Vilà. 2002. “Ancient DNA evidence for old world origin of new world dogs." Science 298 (5598): 1613-1616.

Levine, M. A. 1999. "Botai and the Origins of Horse Domestication." Journal of Anthropological Archaeology 18 (1): 29-78.

Levine, M. A., K. E. Whitwell, and L. B. Jeffcott. 2005. “Abnormal thoracic vertebrae and the evolution of horse husbandry." Archaeofauna, no. 14, 93-109.

Li, Youheng 李有恒. 1974. “Dawenkou muqun de shougu ji qita dongwu guge” 大汶口墓群的兽 骨及其他动物骨骼 [Animal Bones at the Dawenkou Cemetery Site]. In Dawenkou 大汶口， edited by Shandong Provincial Cultural Relics Administration and Jinan Museum, 156-163. Beijing: Cultural Relics Press.

Li, Youheng, and Han Defen. 1959. “Shaanxi Xi' an Banpo Xinshiqi Shidai yizhi zhong zhi shoulei guge” 陕西西安半坡新石器时代遗址中之兽类骨骼 [Animal Remains in Neolithic Sites of Banpo Village, Xi'an, Shaanxi Province]. Gujizhui dongwu yu gurenlei 古脊椎动物与古人类 [Paleovertebrata et Paleoanthropologia] 1 (4): 173-185.

Liu, Li 刘莉, Chen Xingcan 陈星灿, and Yang Dongya 杨东亚. 2006. “Zhongguo jiayang shuiniu qiyuan tantao" 中国家养水牛起源探讨 [On the Origin of the Domestic Buffalo in China]. Kaogu xuebao, no. 2, 141-178.

Liu, Yuyang 刘羽阳. 2013. “Xianqin shiqi jiama yanjiu” 先秦时期家马研究 [On Domestic Horses in the Pre-Qin Period]. PhD thesis, CASS.

Loftus, R. T., D. E. MacHugh, D. G. Bradley, P. M. Sharp, and P. Cunningham. 1994. "Evidence for two independent domestications of cattle." Proceedings of the National Academy of Sciences of the United States of America 91 (7): 2757-2761.

Luo, Yunbing 罗运兵. 2009. “Guanzhong diqu shiqian dongwu kaoguxue yanjiu de jige wenti” 关中地区史前动物考古学研究的几个问题 [Archaeological Research on Prehistoric Animals in the Central Shaanxi Plain]. Kaogu yu wenwu 考古与文物 [Archaeology and Cultural Relics], no. $5,89-94$.

Luo, Yunbing. 2012. Zhongguo gudai zhulei xunhua siyang yu yishixing shiyong 中国古代猪类驯化、 饲养与仪式性使用 [The Domestication, Foddering, and Ritual Use of Pigs in Ancient China]. 
Beijing: Science Press.

Luo, Yunbing, and Yuan Jing. 2005. "Guancha yezhu xiang jiahzhu zhuanbian de xin shijiao" 观 察野猪向家猪转变的新视角 [A New Perspective on the Transformation of Boars to Pigs]. Zhongguo wenwu bao 中国文物报 [China Cultural Relics News], April 1, 2005, 7.

Luo, Yunbing, and Zhang Juzhong 张居中. 2008. “Henan Wuyangxian Jiahu yizhi chutu zhugu de zaiyanjiu” 河南舞阳县贾湖遗址出土猪骨的再研究 [Restudy of Pig Bones Unearthed from the Jiahu Site in Wuyang County, Henan Province]. Kaogu, no. 1, 90-96.

Lü, Peng 吕鹏. 2010. “Shilun Zhongguo jiayang huangniu de qiyuan” 试论中国家养黄牛的起源 [On the Origin of Domestic Cattle in China]. In Dongwu kaogu 动物考古 [Zooarchaeology], edited by Henan Provincial Institute of Cultural Relics and Archaeology, 1:152-176. Beijing: Science Press.

Lü, Peng, Yang Mengfei 杨梦菲, and Yuan Jing. 2007. “Yuxian Wadian yizhi dongwu yihai de jianding he yanjiu” 禹县瓦店遗址动物遗骸的鉴定和研究 [Identification of and Research on Animal Remains at the Wadian Site in Yu County]. In Dengfeng Wangchenggang kaogu faxian yu yanjiu (2002-2005) 登封王城岗考古发现与研究（2002 2005） [Archaeological Discovery and Research of Wangchenggang, Dengfeng (2002-2005)], edited by School of Archaeology and Museology, Peking University and Henan Provincial Institute of Cultural Heritage and Archaeology, 815-901. Zhengzhou: Elephant Press.

Lü, Peng, Yuan Jing, and Li Zhipeng 李志鹏. 2014. “Zailun Zhongguo jiayang huangniu de qiyuan" 再论中国家养黄牛的起源 [Further Discussion on the Origin of Domestic Cattle in China]. Nanfang wenwu 南方文物 [Cultural Relics in Southern China], no. 3, 48-59.

MacHugh, D. E, and D. G. Bradley. 2001. "Livestock genetic origins: Goats buck the trend." Proceedings of the National Academy of Sciences of the United States of America 98 (10): 5382-5384.

Marshall, F., and E. Hildebrand. 2002. "Cattle Before Crops: The Beginnings of Food Production in Africa." Journal of World Prehistory 16 (2): 99-143.

Meadow, R. H. 1996. "The origins and spread of agriculture and pastoralism in northwestern South Asia." In The Origins and Spread of Agriculture and Pastoralism in Eurasia, edited by D. R. Harris, 390-412. London: UCL Press.

Nishimoto, Toyohiro 西本豊弘. 1999. 家畜 [Livestock]. In 考古学と動物学 [Archaeology and Zoology], edited by Nishimoto Toyohiro and Matsui Akira 松井章. Tokyo: Douseisha Press 同成社.

Pang, J., C. Kluetsch, Zou X., Zhang A., Luo L., H. Angleby, A. Ardalan, et al. 2009. “mtDNA data indicates a single origin for dogs south of Yangtze River, less than 16,300 years ago, from numerous wolves." Molecular Biology and Evolution 26 (12): 2849-2864.

Patel, A., and R. Meadow. 1998. "The exploitation of wild and domestic water buffalo in prehistoric northwestern South Asia." In Archaeozoology of the Near East III ARC Publicaties, edited by H. Buitenhuis, L. Bartosiewicz, and A. M. Choyke, 18:180-198. Groningen: Centre for Archaeological Research and Consultancy.

Qi, Guoqin 祁国琴. 1989. “Zhongguo beifang Disiji buru dongwuqun” 中国北方第四纪哺乳动物 群 [Quaternary Mammalian Fauna in Northern China]. In Zhongguo yuangu renlei, edited by Wu Rukang, Wu Xinzhi, and Zhang Senshui, 282-307. Beijing: Science Press.

Qi, Guoqin. 1998. “Donghuishan mudi shougu jianding baogao” 东灰山墓地兽骨鉴定报告 [Identification Report on Animal Bones from the Donghuishan Cemetery Site]. In Minle Donghuishan kaogu 民乐东灰山考古 [Archaeology of Donghuishan in Minle County], edited by 
Gansu Provincial Institute of Cultural Relics and Archaeology and Northern Archaeology Laboratory of Jilin University, 184-185. Beijing: Science Press.

Qinghai Provincial Archaeological Team. 1979. “Qinghai Minhe Hetaozhuang Majiayao leixing diyihao muzang” 青海民和核桃庄马家窑类型第一号墓葬 [Tomb No. 1 (Majiayao Type) at Hetaozhuang, Minhe, Qinghai Province]. Wenwu 文物 [Cultural Relics], no. 9, 29-32.

Rackham, James. 1994. Animal Bones. London: British Museum Press.

Reitz, E. J., and E. S. Wing. 2008. Zooarchaeology. Cambridge: Cambridge University Press.

Shijiahe Archaeological Team, ed. 1999. Xiaojiawuji 肖家屋脊. Beijing: Cultural Relics Press.

Tchernov, E., and F. F. Valla. 1997. "Two new dogs, and other Natufian dogs, from the southern Levant." Journal of Archaeological Science 24 (1): 65-95.

Tong, Haowen 同号文. 2004. “Cong dongwu xunyang tan jinhua wenti” 从动物驯养谈进化问题 [On Evolution from the Perspective of Animal Domestication]. Huashi 化石 [Fossils], no. 2, 30-33.

Vilà, C., P. Savolainen, J. E. Maldonado, I. R. Amorim, J. E. Rice, R. L. Honeycutt, K. A. Crandall, J. Lundeberg, and R. K. Wayne. 1997. "Multiple and ancient origins of the domestic dog." Science 276 (5319): 1687-1689.

West, B., and Zhou B. 1988. "Did chickens go North? New evidence for domestication." Journal of Archaeological Science 15 (5): 515-533.

$\mathrm{Wu}$, Xiaohong 吴小红, Xiao Huaide 肖怀德, Wei Caiyun 魏彩云, et al. 2007. “Henan Xinzhai yizhi ren, zhu shiwu jiegou yu nongye xingtai he jiazhu xunyang de wending tongweisu zhengju” 河南新些遗址人、猪食物结构与农业形态和家猪驯养的稳定同位素证据 [Stable Isotopic Evidence for the Food Structure of Humans and Pigs, and Agricultural Forms and Pig Domestication at the Xinzhai Site, Henan]. In Keji kaogu, edited by the Center for Scientific Archaeology, Institute of Archaeology, CASS, 2:49-58. Beijing: Science Press.

Yang, Jie 杨杰. 2008. “Erlitou yizhi chutu dongwu yicun yanjiu” 二里头遗址出土动物遗存研究 [On the Fauna Remains at the Erlitou Site]. In Zhongguo zaoqi Qingtong wenhua 中国早期青铜文 化 [The Early Bronze Culture in China], edited by Institute of Archaeology, CASS, 470-539. Beijing: Science Press.

Yuan, Jiarong 袁家荣. 2000. “Hunan Daoxian Yuchanyan 1 wannian yiqian de daogu he taoqi” 湖南道县玉蟾岩 1 万年以前的稻谷和陶器 [Rice and Pottery 10,000 years BP at Yuchanyan, Dao County, Hunan Province]. In Daozuo taoqi he dushi de qiyuan 稻作陶器和都市的起源 [The Origins of Rice Agriculture, Pottery and Cities], edited by Yan Wenming 严文明 and Yasuda Yoshinori 安田喜宪, 31-42. Beijing: Cultural Relics Press.

Yuan, Jing. 2001. “Zhongguo Xinshiqi Shidai jiachu qiyuan de wenti” 中国新石器时代家畜起源的 问题 [The Origin of Livestock in the Neolithic Age of China]. Wenwu, no. 5, 51-58.

Yuan, Jing. 2002. “The formation and development of Chinese Zooarchaeology: A preliminary review." Archaeofauna, no. 11, 205-212.

Yuan, Jing. 2003. “Zhongguo gudai jiama de yanjiu” 中国古代家马的研究 [On Domestic Horses in Ancient China]. In Zhongguo shiqian kaoguxue yanjiu 中国史前考古学研究 [Research on Prehistoric Archaeology in China], edited by Shaanxi Provincial Cultural Heritage Administration, Shaanxi Institute of Archaeology, and Xi'an Banpo Museum, 436-443. Xi'an: Sanqin Publishing House.

Yuan, Jing. 2007. “Dongwu kaoguxue jiemi gudai renlei yu dongwu de xianghu guanxi” 动物考 
古学揭秘古代人类与动物的相互关系 [The Relationship between Ancient People and Animals Indicated by Zooarchaeology]. In Xibu kaogu 西部考古 [Archaeology in western China], edited by the Key Laboratory of Ministry of Education for the Preservation and Conservation of Cultural Heritage and the Cultural Heritage and Archaeological Research Center of Northwest University, 2:82-95. Xi'an: Sanqin Publishing House.

Yuan, Jing. 2009. “Zhongguo Xinshiqi Shidai shiyong zhu jinxing jisi he suizang de yanjiu” 中国 新石器时代使用猪进行祭祀和随葬的研究 [On the Sacrifice and Funerary Burial of Pigs in the Neolithic Age in China]. Yu Weichao xiansheng jinian wenji xueshu juan 俞伟超先生纪念文集・学 术卷 [A Memorial Collection for Mr. Yu Weichao: Academic Publications], edited by School of Archaeology and Museology, Peking University and the National Museum of China, 175-192. Beijing: Cultural Relics Press.

Yuan, Jing, and Rowan K. Flad. 2002. "Pig domestication in ancient China." Antiquity 76 (293): 724-732.

Yuan, J., and R. Flad. 2006. "Research on early horse domestication in China." In Equids in Time and Space, edited by Marjan Mashkour, 124-131. London: Oxbow Books.

Yuan, Jing, Huang Yunping 黄蒀平, Yang Mengfei, Lü Peng, Tao Yang 陶洋, and Yang Jie. 2007. “Gongyuanqian 2500 nian zhi gongyuanqian 1500 nian Zhongyuan diqu dongwu kaoguxue yanjiu” 公元前 2500 年至公元前 1500 年中原地区动物考古学研究 [Archaeological Study on Animals in the Central Plains from 2500 BCE to 1500 BCE]. In Keji kaogu, edited by the Center for Scientific Archaeology, Institute of Archaeology, CASS, 2:12-34. Beijing: Science Press.

Yuan, Jing, and Li Jun 李君. 2010. “Hebeisheng Xushuixian Nanzhuangtou yizhi chutu dongwu guge yanjiu baogao" 河北省徐水县南庄头遗址出土动物骨骼研究报告 [Report on Animal Remains Unearthed from the Nanzhuangtou Site in Xushui County, Hebei Province]. Kaogu xuebao, no. 3, 385-392.

Zeder, M. A., and B. Hesse. 2000. “The Initial Domestication of Goats (Capra hircus) in the Zagros Mountains 10,000 years ago." Science 287 (5461): 2254-2257.

Zhang, Changshou 张长寿, and Zhang Guangzhi 张光直. 1997. “Henan Shangqiu diqu Yinshang wenming diaocha fajue chubu baogao” 河南商丘地区殷商文明调查发掘初步报告 [Preliminary Report on the Investigation and Excavation of the Shang Civilization at Shangqiu, Henan]. Kaogu, no. 4, 24-31, 97.

Zhang, Juzhong 张居中. 1999. “Shou keng” 兽坑 [Animal Pit]. In Wuyang Jiahu 舞阳贾湖 [Jiahu, Wuyang], edited by Henan Provincial Institute of Cultural Heritage and Archaeology, 130. Beijing: Science Press.

Zhou, Benxiong 周本雄. 1981. “Hebei Wu'an Cishan yizhi de dongwu guhai” 河北武安磁山遗址 的动物骨骸 [The Animal Remains Discovered at Cishan Village, Wu'an, Hebei Province]. Kaogu xuebao, no. 3, 339-346.

Zhou, Benxiong. 1983. “Baoji Beishouling Xinshiqi Shidai yizhi zhong de dongwu guhai” 宝鸡北 首岭新石器时代遗址中的动物骨骸 [Animal Bones at the Neolithic Site of Beishouling, Baoji]. In Baoji Beishouling 宝鸡北首岭 [Beishouling in Baoji], edited by Institute of Archaeology, CASS, 145-153. Beijing: Cultural Relics Press.

Zhou, Benxiong. 1999. “Shizhaocun yu Xishanping yizhi de dongwu yicun” 师赵村与西山坪遗址的 动物遗存 [Animal Remains at the Shizhaocun and Xishanping Sites]. In Shizhaocun yu Xishanping, edited by Institute of Archaeology, CASS, 53. Beijing: Encyclopedia of China Publishing House. 


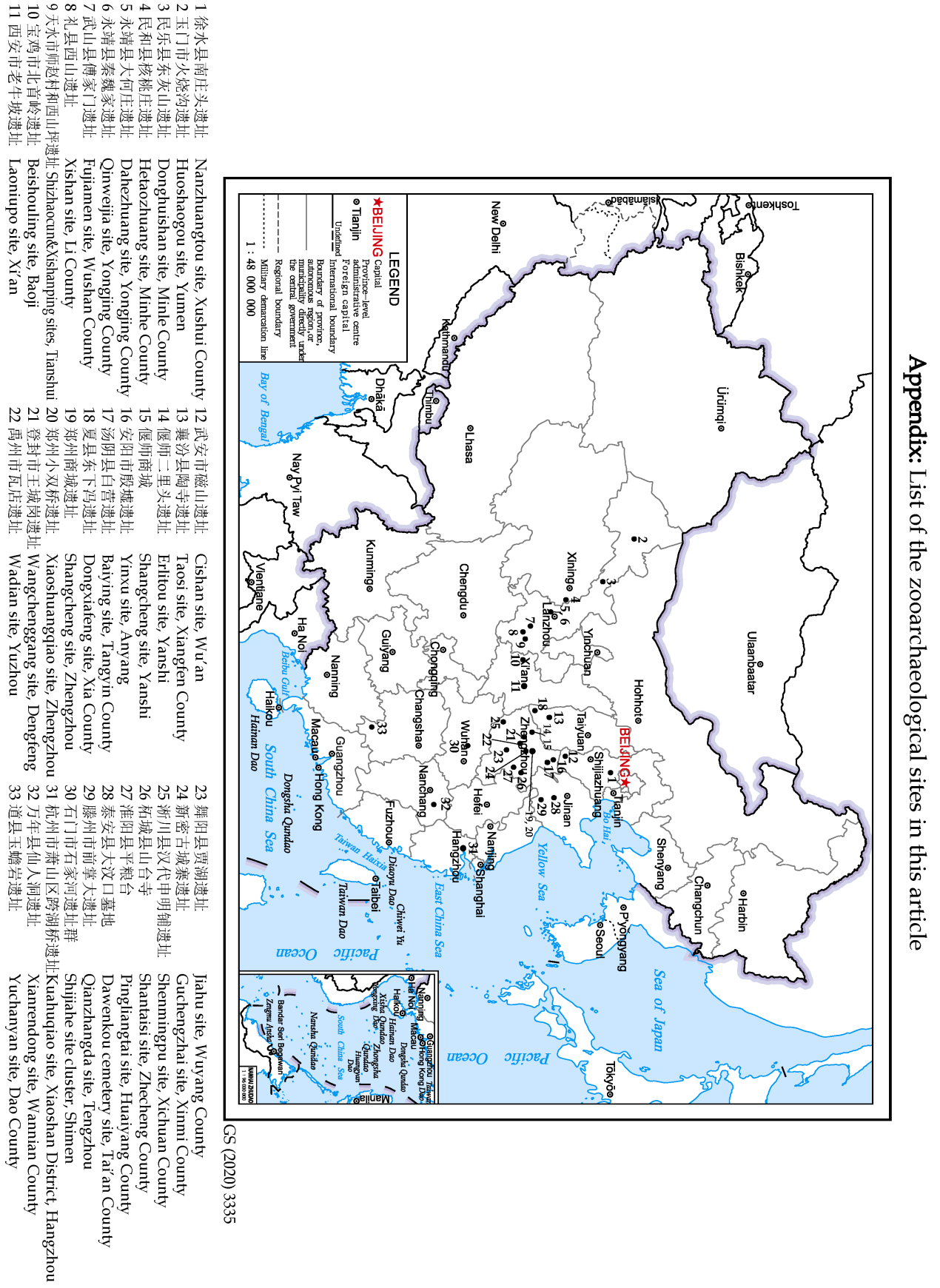

